\title{
Evaluation of immunohistochemical expression of ghrelin-producing rectal cells in Wistar rats underwent to the cafeteria $\operatorname{diet}^{1}$
}

\author{
Humberto Fenner Lyra Junior ${ }^{I}$, Leonardo de Lucca Schiavon" ${ }^{\mathrm{II}}$, Daniella Serafin Couto Vieira ${ }^{\mathrm{III}}$, André Muller Teive ${ }^{\mathrm{IV}}$, Aline \\ Costa $^{\text {, }}$ Tiago Rafael Onzi ${ }^{\mathrm{VI}}$, Angélica Luciana Nau ${ }^{\mathrm{VII}}$, Armando José d'Acampora ${ }^{\mathrm{VIII}}$ \\ IFellow Master degree, Postgraduate Program in Medical Sciences, Department of Surgery, University Hospital, Federal University of Santa Catarina \\ (UFSC), Florianopolis-SC, Brazil. Conception and design of the study; acquisition, analysis and interpretation of data, manuscript writing.

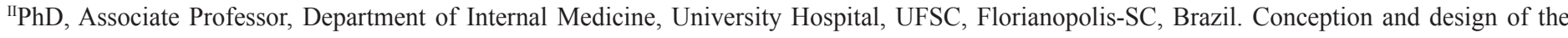 \\ study, analysis and interpretation of data. \\ IIIMaster, Assistant Professor, Department of Pathology, University Hospital, UFSC, Florianopolis-SC, Brazil. Interpretation of histopathological \\ results.

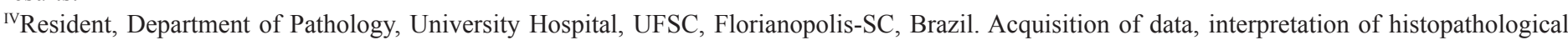 \\ results. \\ ${ }^{\mathrm{v}}$ Master, Department of Pathology, University Hospital, UFSC, Florianopolis-SC, Brazil. Acquisition and interpretation of data. \\ ${ }^{\mathrm{V}}$ Fellow Master degree, Postgraduate Program in Medical Sciences, Department of Surgery, University Hospital, UFSC, Florianopolis-SC, Brazil. \\ Acquisition of data. \\ ${ }^{\mathrm{VII}}$ Graduate student, Medicine Course, UFSC, Florianopolis-SC, Brazil. Acquisition of data. \\ VIIIPhD, Associate Professor, Department of Surgery, University Hospital, UFSC, Florianopolis-SC, Brazil. Conception and design of the study, final \\ approval.
}

\section{ABSTRACT}

PURPOSE: To investigate the impact of cafeteria diet on ghrelin expression in rectal tissue and identify the morphologic cell type.

METHODS: Twenty-four male Wistar rats were divided into four subgroups of six animals each: RC1 (rat chow 1) and CAF1 (cafeteria diet 1) for a period of 30 days; RC2 (rat chow 2) and CAF2 (cafeteria diet 2) for a period of 60 days. The animal and rectal weight, the number and the type of immunoreactive ghrelin cells were recorded and compared between the subgroups. The statistical study was established by ANOVA and Student's t test.

RESULTS: There was no difference in the total of immunoreactive cells $(\mathrm{p}=0.685)$ between the subgroups nor between weight and presence or absence of ghrelin expression $(\mathrm{p}=0.993)$. All the immunoreactive cells identified were closed-type.

CONCLUSION: The cafeteria diet did not have influence on the amount of immunoreactive rectal cells of ghrelin and only one type (closed-type) of immunoreactive cells was expressed in the rectum.

Key words: Ghrelin. Obesity. Colorectal Neoplasms.. Diet, High-fat. Immunohistochemistry. Rats. 


\section{Introduction}

Nowadays obesity and overweight are an epidemic and a public health problem and its prevalence is increasing in developed and developing countries ${ }^{1-2}$.

In 2008, 1.5 billion adults were overweight, and one third of them were obese. Among children up to the 5th year of life, 43 million were overweight in 2010. The World Health Organization (WHO) estimates that, in 2015, there will be over 700 million people with body mass index (BMI) over $30^{3}$.

The main causes of obesity are defined by WHO as: increase intake of high energy density foods, salt and sugar, and few vitamins and minerals; associated with sedentary habits manly due to urbanization and technological advances ${ }^{4}$.

Obesity is identified as an important colorectal cancer risk factor in several studies published in the literature, that demonstrates a risk increase of up to twice in obese people in comparison with non-obese $\mathrm{e}^{5-6}$.

Ghrelin, a hormone discovered and isolated by Kojima et $a l .^{7}$ in the X/A like cells of the fundus of rat stomach ${ }^{7}$. It exhibits a potent orexigenic action, stimulating appetite and food intake by direct action on hypothalamic neurones ${ }^{8}$. In humans, it is peptide composed of 28 amino acids and contains a fatty acyl group on the third amino acid from the $\mathrm{N}$-terminal which is responsible for its physiological functions, this structure is homologous to the rats except for exchange in two amino acids $\left(\arg ^{11}-\mathrm{val}^{12}\right)^{7}$. The major producing source of serum ghrelin is the gastrointestinal tract (GIT), and the stomach is the mainly producer, followed by small intestine ${ }^{9}$. Through immunohistochemical methods and in situ hybridization, ghrelin producing cells were identified in the mucosal layer of the gastric body, duodenum, ileum, cecum and colon at different levels of expression ${ }^{10}$. Despite this Teive et al. ${ }^{11}$ showed no compensatory increase in the number of duodenal ghrelin cells in the post-operative period of the sleeve gastrectomy in rats.

There are two distinct morphological cells types, "opened type" and "closed-type", with identical immunoreactive characteristics, but with different distribution along the gastrointestinal segments, decreasing the frequency of closed-type as it progresses toward the distal segments of the GIT ${ }^{12}$.

Ghrelin is considered to be a gastrointestinal peptide and presumably the opened-type cells are regulated by intraluminal information as nutrients and $\mathrm{pH}$, and the closed-type, by neuronal and hormonal stimulation or mechanical distention. Also there is no literature consensus whether they are the same cells at distinct stages of development or two different cells types ${ }^{13}$.
Waseem et al. ${ }^{14}$ did a study with the aim of determine the role of the endogenous ghrelin production and the expression of its receptors subtypes in the progression of colorectal cancer (CRC), they compared and analyzed malignant with normal colonic cells. They demonstrated by immunohistochemical analysis that malignant colorectal tissues exhibited high ghrelin expression in stage-dependent manner when compared with controls. Likewise, they have used PCR and Western Blot techniques to analyze the growth hormone secretagogue receptors (GHS-Rs) and have found a drastic decrease in la type tissue expression and significant increase in $1 \mathrm{~b}$ type compared between groups, suggesting another regulatory pathway in the genesis of these tumors, not identified until present day.

Another important finding of this study was the high ghrelin serum levels found in obese patients with CRC $(82 \%)$ when compared to obese patients without CRC, suggesting the importance of ghrelin/GHS-Rs axis in the development of CRC in obese people.

Cefeteria diet is a diet model used in experimental studies with rats. It is that best reproduces and induces the metabolic syndrome, the weight gain, the multiple organ dysfunctions and the diseases caused by obesity. This is a type of diet in which the animals have ad libitum intake of human foods with high energy density and tasty as chocolates, bacon, stuffed biscuits, soft drinks, along with water and rat chow ${ }^{15}$.

Recently, the same diet was used for a period of 35 days (short-term) by Colombo et al. ${ }^{16}$ in research on effect on insulin resistance and serum levels of adiponectin and ghrelin and showed a significant weight gain on the cafeteria group when compared with controls.

The purpose of this work was to evaluate the impact of cafeteria diet on the amount of rectal ghrelin producing cells and analyzed the morphological cell type found in the rectum by imunohistochemical method.

\section{Methods}

The Federal University of Santa Catarina Committee of Ethics in the Use of Animals (CEUA) approved all the animal experimental procedures in May 11, 2011 (protocol \# PP00591 23080.009228/2011-89).

Twenty four male Wistar rats weighing 250-300g were used in this experiment. The animals were randomly allocated into four subgroups of six rats each: cafeteria diet 1 (CAF1), rat chow 1 (RC1), cafeteria diet 2 (CAF2) and rat chow 2 (RC2). 


\section{Dietary management}

Following a one week period of adaptation the rats in the CAF subgroups were fed on a cafeteria-style diet consisting of $45 \%$ carbohydrates, $45 \%$ lipids, $10 \%$ proteins, while the rats in the RC subgroup were fed on standard rat chow consisting of $55 \%$ carbohydrates, $22 \%$ proteins and $5 \%$ lipids (Nuvilab $\mathrm{Cr}-1$, Nuvital, PR, Brazil). All rats were given water ad libitum.

The CAF1 and RC1 subgroups were fed over a period of 30 days and the CAF2 and RC2 subgroups were fed over a period of 60 days. In order to determine the development of the animals, the weights values were recorded weekly and on the day of surgery (Figure 1).

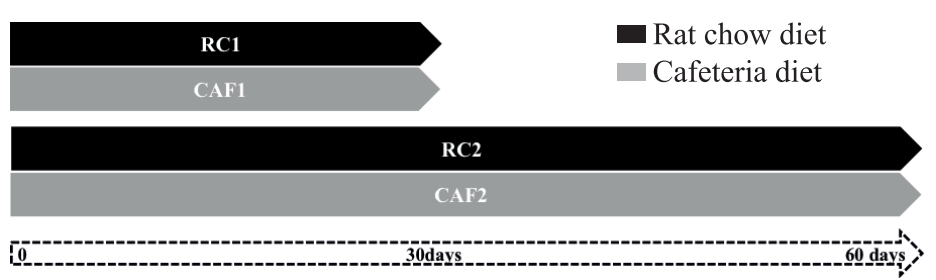

FIGURE 1 - Schematic drawing showing the feeding period.

\section{Surgical procedures}

After the end of feeding period the rats were anesthetized with an intramuscular injection of $100 \mathrm{mg} / \mathrm{kg}$ of ketamine and $10 \mathrm{mg} / \mathrm{kg}$ xylazine.

The animals were submitted to a midline laparotomy for resection of the rectum. The specimens were preserved in a $10 \%$ buffered formaldehyde solution. All the resected rectal segments were numbered and coded by Arabic numbers (1 to 24). The rats were euthanized by intramuscular injection of ketamina $300 \mathrm{mg} / \mathrm{kg}$ and $30 \mathrm{mg} / \mathrm{kg}$ xylasina.

\section{Histophatological procedures}

A midline longitudinal strip of rectal specimens, $2 \mathrm{~mm}$ wide on anterior rectal wall was cut to be fixed on a microscopic slide. The specimens were processed, and paraffin blocks were prepared to make slides for both hematoxylin-eosin and immunohistochemical staining.

\section{Immunohistochemistry}

Tissues were stained immunohistochemically using the labeled streptavidin biotin method (LSAB). Briefly, the specimens were deparaffinized, rehydrated and incubated with
$0.3 \%$ hydrogen peroxide in methanol for 20 minutes to block endogenous peroxidase activity. Antigen retrieval was performed using citrate buffer ( $\mathrm{pH} \mathrm{6.0)}$ ) for 40 minutes at $95-98^{\circ} \mathrm{C}$, and the specimens were left to cool for 30 minutes at room temperature.

The specimens were incubated with primary rabbit anti-ghrelin (rat-mouse) antibody (Phoenix Pharmaceuticals, CA, USA) diluted 1:10.000 for 12 hours at $8^{\circ} \mathrm{C}$ in a humidified chamber and with the biotinylated secondary antibody (Dako, CA, USA) for 30 minutes at room temperature.

The specimens were incubated with streptavidin conjugated to peroxidase (Dako, CA, USA) for 40 minutes at room temperature and were treated for one minute with 3-3diaminobenzidine (DAB), which acted as a chromogen.

The specimens were counterstained with Harris hematoxylin for nine minutes, dehydrated in a graded ethanol series, clarified with xylene and mounted under coverslips ERVMOUN (EasyPath, SP, Brazil).

The rat stomach, which is known to express ghrelin, was used as a positive control for the experiment, and the negative control was a specimen that received phosphate buffer solution (PBS) instead of primary antibody. The positive result was indicated by the appearance of brown color in the antibodybinding site.

Morphmetric analysis, cell counting, and statistical analysis

The microscopic slides contained the strips of the rectum were entirely examined by two pathologists blinded to the experimental conditions. They used a light microscope (Optiphot-2, Nikon, Japan) and counted all the immunopositive ghrelin cells. Only the nucleated cells localized in the mucosal layer with brown chromogen in the cytoplasm or in any part of the cell membrane were considered for counting. Three full counting were performed and considered only the cells which had concordance of both observes. The opened and closed-types cells were counted. ANOVA test was used to assess statistical significance, which was set at $\mathrm{p}<0.05$. All the data were expressed as the means and SD and SPSS 17 statistics software (SPSS, Inc., IL, USA) was used for data processing.

\section{Results}

Ghrelin cells were observed in the rectal mucosal layer and not found in other layers. All the immunopositive cells foud were small and rounded shaped and classified as closed-type cells 
(Figure 2).

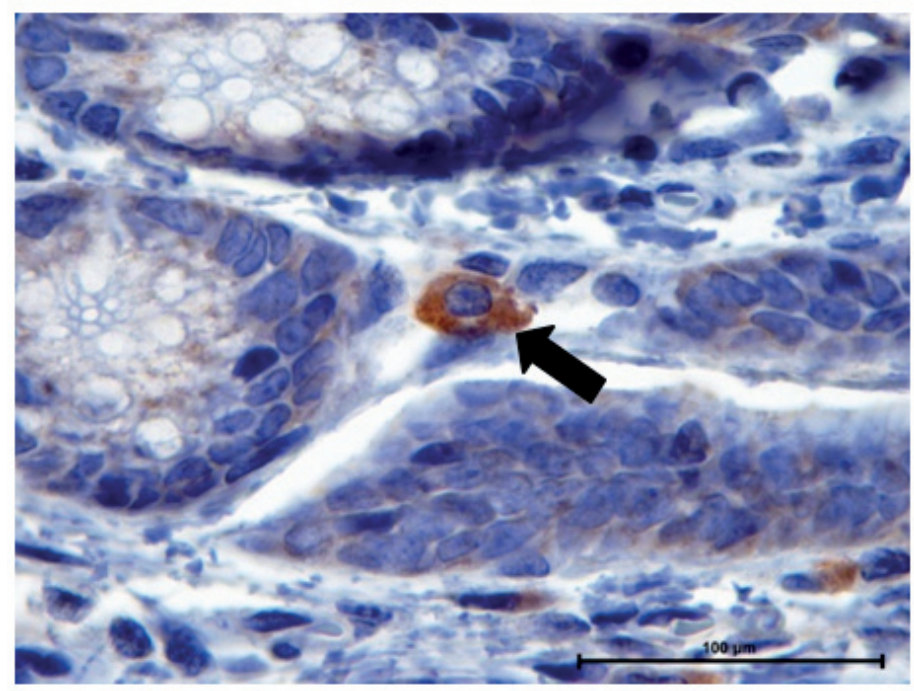

FIGURE 2 - Ghrelin immunopositive closed-type cells in rectal mucosal layer (arrow) (x400).

Weight gain was recorded weekly and the averages of final weight (operation day) in the subgroups were: CAF1 349.50g; RC1 339.83g; CAF2 411.33g and RC2 327.33g. There was statistical difference in comparison between CAF2 and the other groups and there was no difference in other comparisons (Table 1).

TABLE 1 - Mean and standard deviation (SD) of body weight on the operation day for different subgroups: CAF1, RC1, CAF2 and RC2.

\begin{tabular}{ccccc}
\hline Subgroups & CAF1 & RC1 & CAF2 & RC2 \\
\hline Final weight $(\mathbf{g})^{\mathrm{a}}$ & $349.50^{\mathrm{b}}$ & $339.83^{\mathrm{c}}$ & 411.33 & $327.33^{\mathrm{d}}$ \\
\hline SD $^{\mathrm{a}}$ & \pm 24.40 & \pm 22.44 & \pm 31.61 & \pm 36.84 \\
\hline
\end{tabular}

${ }^{\mathrm{a}}$ Mean \pm Standard deviation

${ }^{\mathrm{b}} \mathrm{p}=0.010(\mathrm{CAF} 2 \times \mathrm{CAF} 1)$

${ }^{\mathrm{c}} \mathrm{p}=0.003(\mathrm{CAF} 2 \times \mathrm{RC} 1)$

${ }^{\mathrm{d}} \mathrm{p}=0.001(\mathrm{CAF} 2 \times \mathrm{RC} 2)$

There were similar values of immunopositive cell count for all subgroups and statistical analysis showed no significant difference between them $(\mathrm{p}=0.685)$ as shown in the Table 2 .

Final mean weight compared to the presence or absence of ghrelin expression also had no statistically significant difference $(p=0.993)$ (Table 3).
TABLE 2 - Mean and standard deviation (SD) of immunopositive cell count for different subgroups: CAF1, RC1, CAF2 and RC2.

\begin{tabular}{ccccc}
\hline Subgroups & CAF1 & RC1 & CAF2 & RC2 \\
\hline Cell number & 1.67 & 1.17 & 0.83 & 1.00 \\
\hline SD $^{\mathrm{a}}$ & \pm 1.03 & \pm 1.16 & \pm 1.16 & \pm 1.54 \\
\hline & & & $\mathrm{p}=0.685^{\mathrm{b}}$ \\
\hline
\end{tabular}

a Mean \pm Standard deviation

${ }^{\mathrm{b}}$ ANOVA test

TABLE 3 - Mean and standard deviation (SD) of final weight $(\mathrm{g})$ compared with expression or non-expression of ghrelin.

\begin{tabular}{cccc}
\hline Ghrelin expession & Yes & No & P $^{\mathbf{b}}$ \\
\hline Final weight $(\mathrm{g})^{\mathbf{a}}$ & $356.93 \pm 27.10$ & $357.10 \pm 60.40$ & 0.993 \\
\hline
\end{tabular}

a Mean \pm Standard deviation

b Student's t test

\section{Discussion}

Obesity and overweight induced by diet and lifestyle are considered a global epidemic by the World Health Organization (WHO), especially in western countries. They are important risk factors for several conditions, including colorectal cancer.

Ghrelin has many physiologic functions including the carcinogenesis acting in some steps of cell growing and apoptosis $^{17-18}$. We investigated the hypothesis that weight gain could alter the number of producing ghrelin cells in the segments of the gastrointestinal tract.

Wassen et al. ${ }^{14}$ demonstrated an increase of the ghrelin expression, mainly of the growth hormone secretagogue receptors 1b (GHS-R 1b), in malignant colorectal cells and this condition promoted colorectal malignancy by advancing stage of tumor. That increase was significant when compared CRC obese patients with non-obese.

Based on these this data and on the characteristics of human and rat ghrelin, we designed this study because we believed that obesity could modify the number of ghrelin cells specifically in the rectum leading to local changes that promote premalignant disorders.

Sahin et al. ${ }^{19}$ studied several segments of the gastrointestinal rat tract and showed decrease on ghrelin tissue expression and ghrelin serum levels in rats submitted to diet- 
induced obesity, however these difference was not significant on rectal segment.

These results do not explain the hypothesis that there are a local involvement of ghrelin expression and rectal carcinogenesis.

We analyzed the entire length of the rectum (proximal, middle and distal) and also found no differences between the subgroups that this fact leads us to conclude that obesity do not have influence on ghrelin cells in the rectum.

Although another study demonstrates presence of two distinct types of ghrelin cells in distal segments of GIT with predominance of opened-type ${ }^{12}$ we have found only closed-type cells in the rectum. Further and more detailed studies are needed to identify and determine the ghrelin-producing cells in colorectal segments and its relation to obesity.

\section{Conclusion}

Cafeteria diet did not have impact on the amount of ghrelin-producing cells and only one type (closed-type) was found in the rectum.

\section{References}

1. Flegal KM, Carroll MD, Ogden CL, Johnson CL. Prevalence and trends in obesity among US adults, 1999-2000. JAMA. 2002;288:1723-7.

2. Moura EC, Claro RM. Estimates of obesity trends in Brazil, 20062009. Int J Public Health. 2012;57:127-33.

3. Nguyen DM, El-Serag HB. The epidemiology of obesity. Gastroenterol Clin North Am. 2010;39:1-7.

4. WorldHealthOrganization. (2012) Obesity and Overweight. Available at: www.who.int/mediacentre/factsheets/fs311/en/April 24, 2012.

5. Terry PD, Miller AB, Rohan TE. Obesity and colorectal cancer risk in women. Gut. 2002;51:191-4.

6. Larsson SC, Wolk A. Obesity and colon and rectal cancer risk: a meta-analysis of prospective studies. Am J Clin Nutr. 2007;86:55665.

7. Kojima M, Hosoda H, Date Y, Nakazato M, Matsuo H, Kangawa $\mathrm{K}$. Ghrelin is a growth-hormone-releasing acylated peptide from stomach. Nature. 1999;402:656-60.

8. Nakazato M, Murakami N, Date Y, Kojima M, Matsuo H, Kangawa $\mathrm{K}$, Matsukura S. A role for ghrelin in the central regulation of feeding. Nature. 2001;409:194-8.

9. Ariyasu H, Takaya K, Tagami T, Ogawa Y, Hosoda K, Akamizu T, Suda M, Koh T, Natsui K, Toyooka S, Shirakami G, Usui T, Shimatsu A, Doi K, Hosoda H, Kojima M, Kangawa K, Nakao K. Stomach is a major source of circulating ghrelin, and feeding state determines plasma ghrelin-like immunoreactivity levels in humans. J Clin Endocrinol Metab. 2001;86:4753-8.

10. Gnanapavan S, Kola B, Bustin SA, Morris DG, McGee P, Fairclough $\mathrm{P}$, Bhattacharya S, Carpenter R, Grossman AB, Korbonits M. The tissue distribution of the mRNA of ghrelin and subtypes of its receptor, GHS-R, in humans. J Clin Endocrinol Metab. 2002;87:2988.
11. Teive MB, Russi RF, Vieira DS, Teive AM, Costa A, d'Acampora AJ. Quantitative immunohistochemical analysis of duodenal ghrelin cells after sleeve gastrectomy in Wistar rats. Acta Cir Bras. 2012;27:595-9.

12. Sakata I, Nakamura K, Yamazaki M, Matsubara M, Hayashi Y, Kangawa K, Sakai T. Ghrelin-producing cells exist as two types of cells, closed- and opened-type cells, in the rat gastrointestinal tract. Peptides. 2002;23:531-6.

13. Sakata I, Sakai T. Ghrelin cells in the gastrointestinal tract. Int J Pept. 2010;2010:1-7.

14. Waseem T, Javaid Ur R, Ahmad F, Azam M, Qureshi MA. Role of ghrelin axis in colorectal cancer: a novel association. Peptides. 2008;29:1369-76.

15. Sampey BP, Vanhoose AM, Winfield HM, Freemerman AJ, Muehlbauer MJ, Fueger PT, Newgard CB, Makowski L. Cafeteria diet is a robust model of human metabolic syndrome with liver and adipose inflammation: comparison to high-fat diet. Obesity (Silver Spring). 2011;19(6):1109-17.

16. Colombo G, Bazzo ML, Nogueira CL, Colombo MD, Schiavon LL, d'Acampora AJ. A study on the short-term effect of cafeteria diet and pioglitazone on insulin resistance and serum levels of adiponectin and ghrelin. Braz J Med Biol Res. 2012;45:935-41.

17. Kojima M, Kangawa K. Ghrelin: structure and function. Physiol Rev. 2005;85:495-522.

18. Sato T, Nakamura Y, Shiimura Y, Ohgusu H, Kangawa K, Kojima M. Structure, regulation and function of ghrelin. J Biochem. 2012;151:119-28.

19. Sahin I, Aydin S, Ozkan Y, Dagli AF, Akin KO, Guzel SP, Catak Z, Ozercan MR. Diet-induced obesity suppresses ghrelin in rat gastrointestinal tract and serum. Mol Cell Biochem. 2011;355:299308

\section{Correspondence:}

Humberto Fenner Lyra Junior

Rodovia Haroldo Soares Glavan, 3375/102 vila 2

88050-005 Florianópolis - SC Brasil

Tel.: (55 48)3233-1805

Fax: (55 48)3721-8045

humbertolyrajr@gmail.com

Received: April 23, 2013

Review: June 24, 2013

Accepted: July 22, 2013

Conflict of interest: none

Financial source: Federal University of Santa Catarina (UFSC)

${ }^{1}$ Research performed at Laboratory of Technique and Experimental Surgery, Department of Surgery and Laboratory of Pathology, University Hospital, Federal University of Santa Catarina (UFSC), FlorianopolisSC, Brazil. Part of Master degree thesis, Postgraduate Program in Medical Sciences, UFSC. Tutor: Prof. Armando José d'Acampora. 